\title{
Building Constructive Innovation Networks: The Role of Relationship Management
}

\author{
By \\ Dr Robyn Keast \\ School of Management \\ Queensland University of Technology \\ and \\ Professor Keith Hampson
}

Chief Executive Officer, CRC for Construction Innovation

Please address all correspondence to:

Dr Robyn Keast

School of Management

Queensland University of Technology

GPO Box 2434

Brisbane, Qld 4001

Ph: +61738649429

Fax: +61 738642550

Email: rl.keast@qut.edu.au 


\section{Building Constructive Innovation Networks: The Role of Relationship Management}

The building and construction sector is one of the five largest contributors to the Australian economy and is a key performance component in the economy of many other jurisdictions. However, the ongoing viability of this sector is increasingly reliant on its ability to foster and transfer innovated products and practices. Interorganizational networks, which bring together key industry stakeholders and facilitate the flows of information, resources and trust necessary to secure and diffuse innovation, have emerged as a key growth strategy within this and other arenas. The blending of organizations, resources and purposes creates new, hybrid institutional forms that can draw on a mix of contract, structure and interpersonal relationship as integration processes.

This paper argues that such hybrid arrangements, because they incorporate relational elements, require management strategies and techniques that are not always synonymous with conventional management approaches, including those used within the building and construction sector. It traces the emergence of the Construction Innovation Project in Australia as a hybrid institutional arrangement molding public, private and academic stakeholders of the building and construction industry into a coherent collective force aimed at fostering innovation and its application within all levels of the industry. Specifically, the paper examines the Construction Innovation Project to ascertain the impact of relational governance and its management to harness and leverage the skills, resources and capacities of members to secure innovative outcomes. Finally, the paper offers a preliminary framework for relationship management to guide the ongoing work of this body and any other charged with a similar integrative responsibility. 



\section{Introduction}

A dynamic and prosperous building and construction sector is considered an essential component of successful modern economies (Winch 1998; Hampson and Manley 2001). Indeed, when the total set of related industries is included, this sector accounts for approximately fifteen (15) per cent of the national product of most nations (Gann and Salter 2000; Seadon and Manseau 2001). However, it is widely argued that the ongoing viability of the sector is dependent on the development of innovation and its uptake as compared to other sectors (Slaughter 2000; Winch, 1998; Blayse and Manley 2004). Innovation in this context refers to "...the actual use of nontrivial change and improvement in a process, product or system that is novel to the institution developing the change" (Freeman 1989).

This push for more innovation is driven by a number of inter-related social and economic forces. The most significant is the demand for alternative building forms and structures, to accommodate cost, resource and environmental considerations as well as increasing demands for a more seamless rollout of construction endeavors (Gann 2000; Hampson and Manley 2001). An ongoing quest for competitive advantage provided by new technologies and processes to more efficiently deliver on projects, particularly the requirements of complex projects and the demands by clients for more cost and time efficient outcomes are also key contributors to innovation (Ling 2003). An increasing pattern of market globalization, which has brought new regions, including those located around the Pacific Rim to the competitive mix within the industry has also created pressures to innovate (Gann, 2000). Finally, continuing rapid advances in information, communication and computational technologies are also presenting new opportunities and challenges 
within the industry. On the importance of innovation to this industry Tatum (1991: 447) has stated:

At the bottom line, engineering and construction firms need to innovate to win projects and to improve the financial results of these projects. They must innovate to compete. Development and effective use of new technology can provide important competitive advantages for engineering and construction firms. These advantages stem from distinctive technical capacity, improvements in operations, and an image as a technically progressive company.

The inability of the construction, building and property sector to create and disperse or draw on and leverage from innovation has been attributed to the traditionally highly fragmented and competitive nature of the sector, spread as it is across a number of industries and levels of operation and a lack of engagement and coordination of effort between academic and industry research, coupled with, in the Australian context at least, a history of poor rates of investment in research and development (Gann 2000; Hampson and Manley 2001; Blayse and Manley 2004; Dewick and Miozzo 2004).

The conventional process for fostering innovation has centered on the establishment of specialized publicly funded research institutions, limited and contested higher education funding and internal industry Research and Development (R\&D) Units. However, these highly individualized and competitive approaches have given way to an understanding that successful innovation is the result of cooperative, interactive processes between collectives of key stakeholders, rather than the province of individuals or separate organizations, including government. Indeed, a growing body of research has demonstrated that successful innovation is the result of partnerships or a team effort between a collective of industry players (Anderson and Manseau 1999; Miozzo and Dewick 2002). 
Through the ongoing transactions and interactions between people and organizations a relatively stable pattern of relationships or inter-organizational network is formed in which members come to know more about each other and their organizations, common goals are established and trust and reciprocity begins to develop. These interpersonal aspects of networks act as an integrating mechanism to bring together previously disparate and even competitive sectors and their resources and enable members to not only secure resources (Thorell 1986), take advantage of economic efficiencies (Jarillo 1988) or tap into their partners' opportunities (Inkpen 1996) but also draw on and leverage off the synergies that are formed to create new and innovative solutions and ideas (Conway 1995; Huxham 1996). The Bureau of Industry Economics (1991: 7) explains the rationale for this shift in innovation production:

For some time, studies of innovation processes have stressed the importance of networks to successful innovation, over-turning the traditional model which characterizes innovation as a linear sequence running from basic research, through product development, to production and marketing. Innovation is now seen as an interactive process requiring intense traffic in facts, ideas and reputational information within and beyond the firm.

In particular, current paradigms in research and development emphasize the need for multi-disciplinary and interactive knowledge production between universities, research institutions and relevant industries, described elsewhere as the 'triple helix model' (Leydesdorff 2000). The porous nature of the boundaries between these sectors allows for enhanced information, knowledge resource and people transfer, results in the formation of a new innovation location or domain occurring at the point 
at which these three sectors overlap. The formation of this new innovation domain is depicted in Figure 1 below.

Figure 1: Tri-sector Innovation Interface

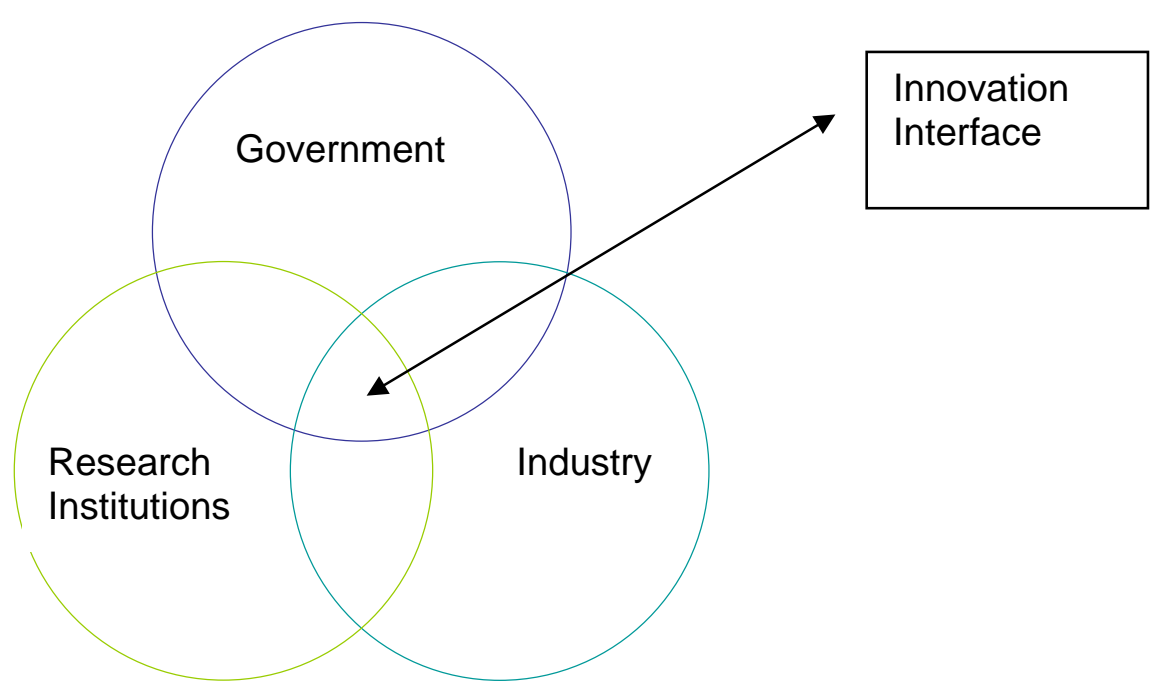

As a consequence, increasingly over the past decade cooperative and collaborative research and development arrangements based on the formation of interorganizational networks have emerged as key strategies to meet these challenges, dissolve organizational barriers and in doing so, foster the development and uptake of innovative techniques and practices necessary to raise the performance of various sectors, including the construction arena (Powell et al. 1996; Swan et al. 2003). Through new policy initiatives, novel public co-financing processes, and new institutional arrangements that blend competitive and cooperative agendas, governments are increasingly supporting such co-joint industry and academic innovation centers. 


\section{Inter-organizational Innovation Networks: Their Governance and Management}

In order to bring these different sectors and their various organizational components into a collective entity, administrators can draw upon three main governance modes or mechanisms of social integration: the hierarchy, the market and social networks. Table 1 sets out the key aspects of each of these governance modes and their idealized associated integration process and management foci.

Table 1: Governance, Management and Integrating Mechanism Schema

\begin{tabular}{|c|c|c|c|}
\hline $\begin{array}{l}\text { Governance } \\
\text { Mode }\end{array}$ & Hierarchy & Market & Networks \\
\hline $\begin{array}{l}\text { Integration } \\
\text { Relationship } \\
\text { orientation }\end{array}$ & $\begin{array}{c}\text { Authority } \\
\text { relationships }\end{array}$ & $\begin{array}{l}\text { Exchange } \\
\text { relationships }\end{array}$ & $\begin{array}{l}\text { Social/communal } \\
\text { relationships }\end{array}$ \\
\hline $\begin{array}{l}\text { Key integration } \\
\text { mechanisms }\end{array}$ & $\begin{array}{l}\text { Centralized \& } \\
\text { legitimate authority, } \\
\text { rules, regulations, } \\
\text { procedures and } \\
\text { legislation }\end{array}$ & $\begin{array}{l}\text { Formalized, legal } \\
\text { contractual } \\
\text { arrangements, } \\
\text { Arms-length } \\
\text { transactions, } \\
\text { bargaining }\end{array}$ & $\begin{array}{l}\text { Interpersonal trust, } \\
\text { mutuality \& reciprocity }\end{array}$ \\
\hline $\begin{array}{c}\text { Institutional } \\
\text { arrangements }\end{array}$ & $\begin{array}{c}\text { Committees; } \\
\text { Working Parties; } \\
\text { Interdepartmental } \\
\text { Committees }\end{array}$ & $\begin{array}{c}\text { Business } \\
\text { Associations; } \\
\text { Corporate Boards }\end{array}$ & $\begin{array}{l}\text { Networked Arrangements; } \\
\text { Collaborations; } \\
\text { Social charters \& } \\
\text { Compacts \& } \\
\text { Roundtables }\end{array}$ \\
\hline $\begin{array}{l}\text { Management } \\
\text { Focus }\end{array}$ & $\begin{array}{l}\text { Administrative } \\
\text { Management }\end{array}$ & $\begin{array}{l}\text { Contractual } \\
\text { Management }\end{array}$ & Relational Management, \\
\hline
\end{tabular}

Source: Keast, Mandell and Brown, 2005

However, as markets are perceived as unable to adequately bundle the relevant resources and capacities between science and industry, and complete vertical integration of the hierarchy restricts flexibility and incentives (Menard 2002) and the networks of relationships based on trust and reciprocity are often insufficient forces to secure necessary directed outcomes (Rhodes 1997; Keast and Brown 2002), often a mix of governance modes will be employed. Such hybrid arrangements (Borys and Jemison 1989) allow for the interaction, often simultaneously, of governance modes 
resulting in combinations and recombinations of contract, formal structure and interpersonal relations as the linking process for these new institutional arrangements (Schaeffer and Loveridge 2002).

The ability to mix governance and management elements has engendered hybrid arrangements with some unique characteristics, such as simultaneous competition and cooperation (Jorde and Teece 1989), highly complex structural arrangements (Mandell and Steelman 2003; Keast et al. 2004), power and loyalty tensions (Agranoff and McGuire 2001b) that challenge pre-existing management strategies and skills because they are not always synonymous with conventional management approaches, including those used within the building and construction sector. Since hybrid arrangements have become important strategic options, the ability to mould the mix of governance and management strategies for effective outcomes has become a key consideration for both practitioners and researchers. In particular the management of the interplay between the various governance aspects and the role of relational governance and its management are not particularly well understood with respect to the operation and durability of hybrid organizational types, including those within the construction sector (Gann and Salter 2000; Ling 2003). This study informs this debate by examining the presence and management of relational governance aspects with the Cooperative Research Centre for Construction Innovation as an exemplar of collaborative research between industry and government research providers and users in the property and construction arena (Hampson et al. 2003).

\section{Research Methodology}

This paper draws on the experiences of the Cooperative Research Centre for Construction Innovation (Cl) project in Australia to expand the understanding of 
hybrid-networked arrangements, particularly the management of these new forms. To build the case study a set of eleven semi-structured interviews was conducted with key network members involved in the establishment and early operation of the cooperative Endeavour. Questions focused on the establishment, expectations, relationships and implementation of the $\mathrm{Cl}$ during its establishment and early phase of operation. Although the interview was administered in an informal process, an interview schedule was used to ensure that all questions were completed and as a mechanism to control the level of interviewer inducted bias (Patton 1990). By tapping into the participants 'lived experience' of the network, the relationships between actors, and the processes undertaken to facilitate this way of working (Yin 2003), a clear picture of the network process could be developed (Marshall and Rossman 1989). Documentary evidence was utilized as an additional source of information as well as to provide confirmation to statements and direct alternative enquiries.

\section{Construction Innovation}

Construction Innovation (Cl) was formally established in July 2001 to "enhance collaboration between researchers, government and industry involved in the construction and property arena" to deliver innovative outcomes required for growth and viability (CRC-CI Strategic Plan, 2003-2008 - Executive Summary). In doing so, the $\mathrm{Cl}$ aims to deliver tools, technologies and management strategies that will improve the long-term effectiveness, competitiveness and dynamics of a viable construction industry (CRC-Cl 2003).

The project was made possible through a seven-year $\$ 14 \mathrm{M}$ grant through the Cooperative Research Centre Program initiated by the Australian government to foster and facilitate cross-sector research and development activities that have 
national economic and social importance (CRC-Cl 2003). This was coupled with $\$ 50$ million in cash and 'in-kind' support from industry, research and government partners. The $\mathrm{CRC}-\mathrm{Cl}$ currently comprises nineteen (19) industry, government and research partners occupying a complementary niche around the property and construction value chain, as well as a body of researchers all involved in and supporting the endeavor. In bringing together and molding this disparate group of construction stakeholders into a functioning network, it is envisaged that collective action toward innovative outcomes would transpire. The overall purpose of the $\mathrm{Cl}$ is articulated below:

The formation of the CRC was driven by a mutual recognition of the need to lift the game and leverage on individual strengths through national and international collaboration. Participants around the value chain have joined together to strive to achieve this (Hampson et al. 2003).

In this way the $\mathrm{Cl}$ network model centers on the transformation from individual efforts or occasional coalitions to a strategic network focused on harnessing the capacities of all stakeholders toward innovative excellence and leveraging from that to enhance and sustain the viability of the industry. Bringing such a diverse set of actors together into an environment that stimulates information flows and innovation, has resulted in a complex structural and governance model that requires a mix of management strategies and processes to be in place and operational.

\section{Governance, Structure and Management Arrangements}

Bringing these dispersed organizational components together into a collective, coherent entity has occurred through a number of integration processes and 
mechanisms. The first relates to the use of the formalized hierarchical structure of a governance board to pull together the 19 stakeholders and the various operational arms of the project, including five research committees, and a research agenda covering three areas of focus, to provide centralized direction to the work program. Such a structure allows for joint planning and decision-making to transpire, both of which are considered key aspects of successful inter-organizational operation (Brown 1984). Reflecting this complex and formalized structural arrangement, highly bureaucratic processes such as a set schedule for reporting, regulation and structured agendas are key instruments of linkage (CRC Annual Report 2004). Providing a further level of integration and tasked with implementing the policy and action directions of the governing board is a Senior Management Team lead by the Construction Innovation Chief Executive Officer. This centralized body acts as a supplementary hub linking the various elements of the $\mathrm{CRC}-\mathrm{Cl}$ and, because of its hands-on role, also functions as an innovation broker.

In addition to these hierarchical governance processes and related management strategies, the $\mathrm{CRC}-\mathrm{Cl}$ also draws on the market mechanisms of contractual arrangements and agreements between participating members as a key integrating process. That is, each of the member organizations (including government) have undertaken to make financial and for some also in kind contributions to the project. In recognition of the risk as well as advantages of cooperation between firms and sectors, within the $\mathrm{CRC}-\mathrm{Cl}$ it appears that for some, relational contracting is a preferred mode of transaction because it recognizes the incompleteness of formalized contracts and the fact that they can be subject to unforeseen changes (Interviews, 4 and 16 April and 28 May 2003). As well as acknowledging a relational aspect to their contractual agreements and interactions most respondents identified the presence of more personalized, and often long- standing relationships that linked them together into collective action (Interviews 12 March, 4 and 29 April, 2003). The 
following statement is indicative of the situation; "There were already relationships there, links between us from past work that helped".

In this way, within the architecture of the $\mathrm{CRC}-\mathrm{Cl}$, it can be seen that three governance modes co-exist. The next section examines the management of the network of relationships that have evolved.

\section{Network Management Aspects and Strategies}

The interview responses indicated that while network members understood that the Construction Innovation has an established and highly organized governance structure and official/conventional management process, they nevertheless saw themselves involved in a different way of working; one that relies on relationships and relationship building as a key endeavour (Interviews 29 April and 28 May, 2003). That is, for most respondents there was a strong realization that to achieve the goals of the $\mathrm{Cl}$ it was necessary to go beyond limited contractual processes to establishing and nurturing enhanced interpersonal relationships between people and to a lesser extent their parent company. Commenting on the value of relationships in this mode of working, one respondent succinctly stated:" The people issue is more important" (Interview, 2 April 2003).

Despite the realization of the importance of relationships in facilitating or lubricating the information and trust sharing required for innovation, members were cognizant that to achieve outcomes the relationship process had to be more directive or instrumental than' cups of tea' or 'cup cake parties' (Interviews 16 April and 7 May, 2003). As it was stated:

It doesn't happen by people talking about innovation ... or sitting around ... and dreaming about this stuff. (Interview 16 April 2003). 
Indeed, the observation was made on many occasions that an over-emphasis on process at the expense of direction would only result in 'talk fests' (Interviews 2, 4 and 16 April 2003). Clearly, it was understood and demanded that directed action to drive the relationships and leverage the interactions for outcomes was also required (Interview 14 May).

You can't just go with soft 'bunny hugging'. You can't be satisfied with the warm inner glow. There has to be outcomes that make a difference (Interview 16 April, 2003)

This view is apparent in the following statement that acknowledged the need for:

... focused direction to get on with the job and get the research activity moving rather than what could have turned into a talk fest and perhaps there could have been casualties along the way (Interview 4 April, 2003).

This function has been defined elsewhere as network driving (Keast et al. 2004) and is concerned with the task of keeping the group together but moving toward agreed goals. Within the $\mathrm{Cl}$ the role of driving and managing the network "to make sure something beyond talking happens" was seen largely as the responsibility of the Chief Executive Officer and the Senior Management Team (Interviews 7 and 9 May, 2003).

However, it was also understood that network members had a shared responsibility for the operation and management of the endeavour.

This is a cooperative it is not like Coles with your shopping list. Now the CRC has got to take some responsibility to coordinate and 
make it happen - but so too do industry and government (Interview 16 April, 2003).

Thus, while there was a strong understanding that the $\mathrm{Cl}$ was about relationships, this was coupled with an equally strong and pragmatic expectation that these relationships should be managed, massaged and harnessed to ensure that participating bodies achieved individual and collective outcomes. With its emphasis on molding diverse sets of people and organizations into a more cohesive unit, maximizing interactions, network management differs from more conventional management tasks and orientations (Agranoff and McGuire 2001a). Although a different and relatively new approach, a number of key relational management tasks have been identified. The next section compares the respondents' comments on relational or network management with the extant literature on network management.

\section{Construction innovation Network Management Strategies and Tasks: Findings and Discussion}

Four key network management tasks have been identified: activating, framing, mobilizing and synthesizing (Kickert et al. 1997; Agranoff and McGuire 2001a \& b). As the following will demonstrate, although in some ways overlapping, these represent an alternative way of managing and therefore require some very specific and deliberative strategies to put into effect those management principles and techniques.

\section{Activating}

Activation refers to the need to identify and select the appropriate actors and stakeholders as well as the ability to tap into their skills, knowledge and resources 
(Agranoff and McGuire 2001a: 13). This is important because "resources like money, information and expertise are the integrating mechanisms of networks" (13). There was a strong awareness and deliberative strategy on the part of the $\mathrm{Cl}$ personnel of the need to identify and attract and secure 'buy in' (Interview 7 May, 2003) from appropriate participants to the network. For networks within the construction arena the need to attract and secure relevant players and their resources has been identified as a key task and one which generally resides with the more influential or core network members (Walker and Hampson, 2003). This is evidenced in the following statement, which acknowledged that the involvement of Industry and Government was central to the formation of the network:

A key strategy was to get enthusiasm from Industry and Government agencies ... so our main strategy focus was to put together an initial program that would excite industry partners and Government departments to 'come on board' (Interview 16 April, 2003).

However, as well as focusing on bringing to the table the three big players (research institutions, government and industry) the $\mathrm{Cl}$ 'cast its net wider to secure a broad membership base' (Interview 14 May 2003). This rationale is explained:

[you]Have to have the right collaborative partners - you have to have the right profile of people because innovation is not single faceted it is multi faceted.

It was widely agreed that as well as the involvement of strategic or higher profile members, the inclusion of innovation 'end users', often described by respondents as the: "builder with the 4 tonne 'ute' and the cattle dog" (Interviews 4,16, and 29 April 2003) was a central consideration. 
So part of what we were about was selecting partners who complemented each other around the value chain so we were looking at non-competitive partners from the finance end from the developer end and from the designs and consultants and contractors and operators and refurbishers - wanted a group of companies that fairly represented the national construction industry (Interview 4 April 2003).

A number of respondents identified the strategic use of key or influential personnel as a mechanism to attract high-level industry support and representatives to the $\mathrm{CRC}-\mathrm{Cl}$ (Interview 2 April, 2003). On this it was stated: A key task was getting a chairman to attract other senior members from Industry to come and sit around the table (Interview 16 April, 2003). The presence of a sponsor helps to generate resources and support and provides legitimacy for the project. They were also described as providing the "horsepower to get things moving" (Interview 4 April, 2003).

Respondents also noted that because of the different skill sets and responsibility levels the Construction Innovation would necessarily be comprised of members from a number of different operational levels (Interview 19 March, 2003). Through the activation process the $\mathrm{Cl}$ has come to have a broad based, multilevel membership composition, which has contributed to its structural complexity and governance. In this way, activation is about establishing the structure or shape of the network and creating a legitimate foundation for the network even before interactions take place (Mandell 2000).

Further, by consciously attempting to engage all relevant actors to an issue, the full complement of resources, skills and knowledge are brought to the project and can be applied to improve decision-making (Innes and Booher 1999), leverage off new 
resources (Lowndes and Skelcher 1998) and secure innovative ideas and solution through synergistic interactions (Mackintosh 1992; Huxham 1996). There was broad awareness of and expectation by respondents for synergies through interaction and prior relationships (Interviews 4 April and 16 April, 2003). An example of this is noted below:
A system can have a behavioral outcome, which is completely different from what you might expect from looking at the individual components although it is developing that synergy. All the individuals have their various inputs and fire it up and you will hopefully get some results coming out (Interview 2 April, 2003)

Similarly, respondents were aware of and looked to gain benefit from the potential to leverage off the network capital of the $\mathrm{CRC}-\mathrm{Cl}$ and gain added advantages. "So there are great opportunities now that we have leveraged up to be of national significance" (Interview 4 April, 2003).

The withdrawal of funding by an initial network participant required that the some changes be made to the structure and operation of the network and necessitated a refocusing of remaining actors (Interview 16 April, 2003). Although initially problematic, this situation provided the opportunity for adjustments to be made and reminded the remaining members of fluidity of network relationships. Overcoming this fluidity and the potential for networks to become static is a further important aspect of network management in this phase. Such 'network tinkering' (Kickert et al. 1997) or deactivation is used when the network composition becomes stale or is not working and there is a need to input new resources or energy to bolster the dynamics of the interactions. 


\section{Framing}

Another network management task identified from the respondents' comments and consistent with the network management literature was that of framing. Framing is a subtle function that involves establishing and influencing the operating rules, values and norms of the network as well as altering the perceptions of the members so that they can see that more is achieved by working together than singularly (Agranoff and McGuire 2001a: 14). The sense of interdependency and the need for a collective approach is apparent in this statement:

So people think that innovation - think that how can we integrate it because any one element of the construction industry cannot operate by itself - it has to be a team effort and that is the complexity of the area. Yes, it is a complex web, but I think that people have to realize the reality is that we are in a complex web and if you deny it nothing will ever get done (Interview, 2 April 2003).

With so many diverse members in a network, framing becomes necessary to get members to look at problems from another perspective or differently, to influence the rules of interaction and to recommend different decision making mechanisms (Agranoff and McGuire 2001a: 14).

Trying to get people to work together, to seek other points of view, the industry perspectives, which are all different (Interview 2 April, 2003). 
That is in order for the network to be effective members need to be able to understand and accept each other's point of view. It has to do with being able to get actors to "step into each others' shoes" (Mandell 1994; 2000). In this way, mutual learning and understanding become the lubricant for more collaborative actions.

And you have a shared understanding because you know these people both personally and professionally (Interview 16 April, 2003).

The same respondent implied that the existing relationship bonds allowed them to take a 'leap of faith' with a high-risk strategy in a previously uncooperative environment.

I knew all the people involved and I saw it from the start and I thought that it was worth giving it a go because we didn't have any other strategies - we were always struggling in construction (Interview 16 April, 2003).

These 'pockets of trust' (Keast et al. 2004: 365) smoothed over some of the riskier aspects of Construction Innovation and paved the way for more collective and collaborative action.

\section{Mobilizing}

Construction Innovation is about a different way of working that requires participants (and their parent organizations) to let go of their previous, wholly independent orientation and commit to a new collective entity. Building shared goals involves convincing others that by working to a shared outcome they can also achieve individual objectives. The relational management emphasis is centered on aligning 
interests and building consensus (Walker and Hampson, 2003). Interview responses indicate that the $\mathrm{Cl}$ became mobilized around a need to shift from independent to interdependent approach to research and development through more cooperative arrangements (Interviews, 12 March and 16 April 2003). The following statement by an industry partner respondent encapsulates the realization of the need for all parties to work together to better achieve their individual and collective goals.

Collective commitment is seen as being the core catalysis for establishing the innovative brokerage function - you can't do it in isolation and you can't do it alone. Federal government cannot legislate nor do it [innovation research] on its own and academia can't do it on its own. Bring all three parties together and you have created a powerhouse for change (Interview 29 April, 2003).

Within the project, at least initially, the task of bringing or mobilizing the members to a view of the strategic whole and committing to the network (Mandell 1988) was partly achieved through the establishment of a common vision or purpose. That is, there was concerted effort directed toward creating a sense of common ownership of the project by all partners (Interviews 19 March, and 2 April, 2003).

What we were trying to do was bring together a whole range of different people who have got different ideas, different values and different egos and agendas and bring them together under one dream (Interview 4 April, 2003).

For some respondents the task of molding these disparate positions into a mutual goal was to be achieved through the articulation of individual and mutual benefits (Interviews 16 April and 14 May, 2003): 
I think that it is about getting together and aligning yourself with a common view and being prepared - you need to be able to understand the value that you can add to the buyer or user of R\&D and also on the other side explain to the researchers the need and benefits of working collaboratively in applied ways (Interview, 4 April 2003).

Mobilizing therefore involves forging coalitions and agreements on the scope of network operations.

The construction industry is very competitive and so it was a major barrier to bring competitors around the table to be jointly involved in research and so we needed to clearly articulate what would be the benefits of doing pre-competitive research which each could then take and apply in their own environments (Interview, 16 April 2003)

It was however acknowledged that this task of securing a common view point was sometimes difficult (Interviews 16 April and 14 May 2003) because it involved 'blue sky ideas' often requiring some hard selling (Interview 16 April, 2003)

With respect to the task of mobilizing for commitment and action, there was strong agreement by respondents on the important role of a centralized network coordinator to champion the project and draw in and connect members to the network, while at the same time drive the project to secure outcomes. On this role it was stated: "that energy pulled lots of people and ideas together" (Interview 4 April, 2003). The value of a strong champion was also noted (Tatum 1984; Nam and Tatum 1997) as essential for innovation and innovative practices. 
Along a similar line, Agranoff and McGuire (2001a) make the important point that network management also has to do with securing the commitment of network members' individual organizations to work through the network. A number of $\mathrm{CRC}-\mathrm{Cl}$ respondents also identified the need to obtain the endorsement of the parent organization, for example it was stated: "[we] Had to get senior management approval and support" (Interviews 16 April and 14 May 2003). It was also observed that this endorsement also afforded network actors the legitimacy to work in a different way and assisted in smoothing the course for funding (Interview 4 April, 2003). According to Bryson (1995) the existence of such a higher-level sponsor helps to generate resources and provides formal authorization for the project, making it less susceptible to policy and political changes (Keast and Brown 2002). Thus, innovation development and innovative practices would seem to benefit from the dual support of both champions and sponsors.

\section{Synthesizing}

Since network management is essentially about molding a set of disparate agencies and people into a collective and functioning whole, a key task centers on dealing with the conflicts that members have both within the network with each other and also the conflicts that arise from the loyalties they feel to their individual organizations and those they may feel to the network. This relates to the fact that members of a network are also members of individual organizations and come with preconceived ideas, values and commitments to their organization (Mandell 2000). Within the $\mathrm{Cl}$ there was some conflict of interest apparent between the network goals and the parent body of some network members (Interviews 16 and 19 April). Refocusing on the imperative for the overall goal of cooperative research outcomes and reasserting the dual benefits of inclusion mostly overcame the potential for individual goals to split the network. 
You have to have an imperative. There has got to be something in it for them [individual organizations]. Some need something that drives them to innovate and that is the promise that they will get better widgets and better economy ... and you have to focus on selling that individual and mutual benefit (Interview 19 March, 2003).

The need to acknowledge and work with tensions and a constructive manner to facilitate creatively was identified by one respondent.

There are still tensions - but creative tensions. This is about changing paradigm stuff - about thinking outside of the box. Getting people to think that this is as much an output of the whole exercise as anything else (Interview 2 April 2003).

Also identified as an important strategy for keeping members 'on board' was a deliberative process of engagement for building and maintaining relationships (Interviews 16 April and 7 May, 2003). This was exemplified in the following:

Constantly going back to industry partners - checking that this is what they want - bringing them along, engaging.

For many respondents, the investment of energy and enthusiasm particularly by the CEO and other core members provided a stimulating environment and motivated people to stay with the program and contribute fully to the creative agenda (Interviews 29 April and 14 May, 2003). 
As well as refocusing incentives and building and maintaining relationships, other synthesizing functions undertaken included developing new rules for interactions, cultural adjustments and changed the roles for members (Kickert et al. 1997; Agranoff and McGuire 2001a \& b; Mandell 1990). Similarly for the CRC-Cl changing the culture of members and their organizations from competitive to cooperative was considered an essential prerequisite for the program to work.

Cannot be complacent ... the need to change attitudes and culture is just as important as technology. Attitude changes will give better outcomes and thus is necessary to go forward (Interview 2 April, 2003).

The following statement reinforced this view:

The biggest impact on management performance was not something that ran faster, but having a different culture (Interview 12 March, 2003).

Gann (2000) and Dulaimi et al. (2002) have also noted the important role that culture change plays in construction innovation and the need for policies and priorities that reflect this goal.

Finally, the need for enhanced, more effective and crosscutting communication among the members was identified as central to achieving synthesis within the $\mathrm{Cl}$. Within networked forms communication must be thick and multi-directional to enable all members to access and draw from the information flows (Ansell 2000). Discussing the construction industry specifically, Walker and Hampson (2003) argue that effective communication is vital for building and sustaining the relationships 
necessary for construction innovation. The realization of the need for a comprehensive and shared communication channel to overcome information asymmetry is evident in the following: "There must be communication around the triangle of industry, government and research" (Interview16 April, 2003). Within the CRC-Cl this need for multiple communication channels was achieved through a comprehensive communication process that included internal mechanisms such as newsletters and email groups and external formalized processes including structured reporting, academic publications and other media outlets as well as an underpinning Information and Communication Technology platform (CRC Annual Report, 2004).

This section has shown that within the Construction Innovation Project considerable attention has been directed toward more alternative management tasks based on relationship building, molding and massaging in order to achieve its goals of innovative outcomes and that these tasks fall within the broad parameters of network management strategies identified in the literature. It would appear however, that this process of relationship management within this context has proceeded mostly on intuition without the benefit of any guiding framework for action.

Drawing on the available network management literature and the insights distilled from the experiences of the $\mathrm{CRC}-\mathrm{Cl}$ respondents a preliminary relational management framework has been developed. 
Table 2: Preliminary Relational Management Framework

\begin{tabular}{|c|c|}
\hline $\begin{array}{l}\text { Relational Management } \\
\text { Roles \& Focus }\end{array}$ & $\begin{array}{c}\text { Task } \\
\text { Components }\end{array}$ \\
\hline Activating & $\begin{array}{ll}\text { o } & \text { Identify and select relevant members }\end{array}$ \\
\hline \multirow{5}{*}{$\begin{array}{l}\text { Forming membership \& } \\
\text { accessing resources }\end{array}$} & o Tap into skills, knowledge \& resources \\
\hline & o Establish structural arrangement \\
\hline & o Achieve 'buy-in' of key people \\
\hline & $\begin{array}{l}\text { o Deactivate or disconnect non-contributing } \\
\text { members }\end{array}$ \\
\hline & $\begin{array}{l}\text { Introduce new actors and resources to } \\
\text { change dynamics }\end{array}$ \\
\hline \multirow[t]{4}{*}{$\begin{array}{l}\text { Framing } \\
\text { Shifting orientation from } \\
\text { single to collective }\end{array}$} & $\begin{array}{l}\text { O Establishing \& influencing rules, values \& } \\
\text { norms of the network \& establishing new } \\
\text { terms of engagement }\end{array}$ \\
\hline & o Introducing and championing new ideas \\
\hline & $\begin{array}{l}\text { o Encouraging members to view issues from } \\
\text { another's perspective - mutual learning }\end{array}$ \\
\hline & $0 \quad$ Stressing the benefit of working together \\
\hline \multirow{5}{*}{$\begin{array}{l}\text { Mobilizing } \\
\text { Securing commitment to } \\
\text { whole or collective } \\
\text { identity }\end{array}$} & $\begin{array}{ll}\text { o } & \text { Establishing common vision, mission }\end{array}$ \\
\hline & $\begin{array}{l}\text { o Securing agreement on scale \& scope of } \\
\text { action }\end{array}$ \\
\hline & $\begin{array}{l}\text { Forging coalitions and subgroups for specific } \\
\text { actions }\end{array}$ \\
\hline & o Driving action for outcomes \\
\hline & o Fostering champions and sponsors \\
\hline Synthesizing & $\begin{array}{ll}\text { o } & \text { Dealing with conflict }\end{array}$ \\
\hline \multirow[t]{5}{*}{$\begin{array}{l}\text { Building \& maintaining } \\
\text { relationships }\end{array}$} & $\begin{array}{l}\text { o Checking involvement level \& sense of } \\
\text { engagement }\end{array}$ \\
\hline & $\begin{array}{l}\text { - Leveraging resources for collaborative } \\
\text { advantage collective benefit }\end{array}$ \\
\hline & o Monitoring relationships and activities \\
\hline & o Establishing network \& innovation culture \\
\hline & o Building communication processes \\
\hline
\end{tabular}

Although preliminary in its conceptualization the framework offers network managers and administrators within the construction arena some direction on which to base their endeavors to effectively bring in a relational aspect to the management of networks that are comprised of different organizations and sectors.

\section{Reflecting on the Impact of Relational Management in a Hybrid Arrangement}

This paper has demonstrated that although the $\mathrm{CRC}-\mathrm{Cl}$ is a hybrid arrangement drawing on a mix of three governance modes, the third pillar of relational governance and its management plays an important role. The existence and perceived importance of relationships within the $\mathrm{CRC}-\mathrm{Cl}$ for achieving a collective approach, is 
consistent with the work of Lowndes and Skelcher (1998) who noted that: "A key to sustaining collaboration appears to involve the underlying presence of network mode of governance even when market and hierarchy predominate (331). In particular the enhanced relationships established and maintained between members have acted as a conduit to bring people, resources and ideas together to foster the synergistic processes necessary for innovation outcomes (Interviews 2 and 4 April, 2003). On this it was stated:

It was a successful synergy of people and ideas that led to a realization that we were actually sitting at quite a substantial level nationally and we were promoting and publishing and being sought after internationally for the work that we were doing on this project and others (Interview 4 April, 2003).

Thus managing the relationships allowed the $\mathrm{CRC}-\mathrm{Cl}$ to move beyond limited contractual arrangements to more beneficial but risky cooperative and collaborative endeavors. The relationships arising from previous contractual and alliance formation were also considered to provide 'fertile ground' for innovation development (Interviews 4 April and 28 May, 2003). In this way, the emphasis on relationships and increased understanding and trust provided a way of limiting contractual disputes and reducing the undertone of competitiveness existing within such arrangements (Interview 28 May, 2003). Further, although a highly complex organizational arrangement of often-disparate actors and of significant size and magnitude, the CRC-Cl has been in existence for more than six (6) years. Given the generally shortlife spans of collaborative arrangements (Limerick et al. 1998) it would appear that as well as helping to 'smooth over' with the dual competition-cooperation dilemma faced in hybrid arrangements, a strong relational aspect has contributed to the durability and sustainability of the $\mathrm{CRC}-\mathrm{Cl}$. 
However, while clearly important to the successful operation of the $\mathrm{CRC}-\mathrm{Cl}$ it is apparent from the respondents' comments that the relationship orientation and its management co-exist with and are supported by two other governance elements. The co-existence of this mix of governance and management strategies was described by one respondent as follows: "It seems to me that the CRC is a top down and bottom up structure" (Interview 12 March, 2003). Indeed, it was apparent from the respondents' comments that at different times a particular governance mode and its associated management style was more dominant, with for example, a more bureaucratic process emerging when the program needed direction for rebidding process (Interview 12 March) or at the formation of the network when there was a strong emphasis on relationship building (Interviews 2 and 4 April, 2003). This finding lends support to the proposition put forward by Lowndes and Skelecher (1998) that, depending on the stage of development of collaboration, different governance aspects, and therefore management strategies will be more relevant. Clearly the task in this context is to be able to mix and match the governance modes (Rhodes 1997; Brown and Keast 2003) and related management strategies to ensure that they best reflect the context of the network and its stage of development. Further, as it suggested by Keast et al. (2005) given the mix of governance modes in place in hybrid arrangements there will also be a need for administrators to be able to move between management strategies and even use them simultaneously.

\section{Conclusions}

Network arrangements have come to the fore as previously competitive organizations look to work together to draw on each other's capacities, share knowledge and gain collaborative advantage for innovation production. Because they draw on elements of

participating bodies and mix their governance arrangements, these hybrid 
arrangements pose new and important management challenges. Although acknowledging the importance of conventional management strategies and techniques in the operation of hybrid arrangements, it is concluded that the high level of interpersonal interaction involved in such tri-sector networks also requires the application of specific network management processes to mould and adjust relationships for the collective action necessary for innovation development and transfer

Networks are a very different way of working and require alternative management skills and process emphasize building and sustaining relationships. The paper has shown that while within the Construction Innovation program there is evidence of network management skills and roles being applied, it would appear that this has been accomplished outside of a clear operating framework. Nevertheless, the paper has distilled some key relational or network management tasks and operational components to guide this endeavour. However, there is a need for capacity building by all parties in order to make the necessary adjustments required for this way of working and managing.

In conclusion, the paper has established that in the formation of networks between sectors, new hybrid governance arrangements are created. The resulting institutional arrangements are comprised of unique characteristics such as a tension between competition and cooperation, and the often concurrent mixing of trust, authority and contract as integrating mechanisms. The ability to adequately monitor and balance these various aspects to achieve optimal results presents as a new and ongoing challenge for managers in this context. 


\section{References}

Agranoff, R., and McGuire, M. (2001a). "After the Network is Formed: Processes, Power and Performance". In M.P. Mandell (ed.) Getting Results Through Collaboration: Networks and Network Structures for Public Policy and Management, Quorum Books, Westport, Ct, 11-29.

Agranoff, R., and McGuire, M. (2001b). "Big Questions in Public Network Management Research" Journal of Public Administration Research and Theory, 11(3), 295-326.

Anderson, F., and Manseau, A. (1999). "A Systematic Approach to generation/Transmission/Use of Innovation in Construction Activities" paper presented to Third International Conference on Technology Policy and Innovation: Global Knowledge and Partnerships - Creating Value in the $21^{\text {st }}$ Century, Austin, Texas, 30 August-2 September.

Ansell, C. (2000). "The Network Polity: Regional Development in Western Europe" Governance, 13(3), 303-333.

Blayse, and Manley, K. (2004). "Key Influences on Construction Innovation." <http://www.construction-innovation>.

Borys, B., and Jemison D. (1989). "Hybrid Arrangements as Strategic Alliances: Theoretical Issues in Organizational Combinations" Academy of Management Review, 14(92), 234-249. 
Brown, W. B. (1984). "Firm-Like Behavior in Markets: The Administered Channel" International Journal of Industrial Organization, 2, 263-276.

Brown, K., and Keast, R. (2003). "Community-Government Engagement: Community Connections Through Networked Arrangements" Asian Journal of Public Administration, 25(1), 107-132.

Bryson, J. (1995). Strategic Planning for Public and Non-Profit Organizations, Jossey Bass, San Francisco.

Bureau of Industry Economics (1991). "'Networks': A Third Form of Organisation” Bulletin on Industry Economics, 10, 5-9.

CRC Construction Innovation (2003). "Building our Future" < $\underline{w w w . c o n s t r u c t i o n-~}$ innovation.onfo>.

CRC Construction Innovation (2004). Annual Report.

Conway, S. (1995). "Informal Boundary Spanning Networks in Successful Technological Innovation" Technology, Analysis and Strategic Management, 7(3), 327-342.

Dewick, P., and Miozzo, M. (2004). "Networks and Innovation: Sustainable Technologies in Scottish Social Housing" R\&D Management, 34(4), 323-333.

Freeman, C. (1989). The Economics of Industrial Innovation, MIT Press, Cambridge. 
Dulaimi, M.F., Ling, Y., and Barjracharya, A. (2002). "Enhancing Integration and Innovation in Construction" Building Research and Information, 30(4), 237-247.

Gann, D.M. (2000). Building Innovation: Complex Constructs in a Changing World, Thomas Telford, London.

Gann, D.M., and Salter A.J. (2000). "Innovation in Project Based, Service-Enhanced firms: The Construction of Complex Products and Systems" Research Policy, 29, 955-972.

Hampson, K., and Manley K. (2001). "Construction Innovation and Public Policy in Australia". In A. Manseau and G. Seaden (eds.) Innovation in Construction: An International Review of Public Policies, Spoon Press, London, 31-59.

Hampson, K., Messer, D., and Manley, K. (2003). "Driving Collaboration in Australian Property and Construction" (draft document -9/3/03).

Huxham, C. (ed.) (1996). Creating Collaborative Advantage. Sage London.

Huxham, C. (2000). "The Challenge of Collaborative Advantage" Public Management, 2, 337-357

Inkpen, A.C. (1996). "Creating Knowledge Through Collaboration" California Management Review, 39(1), 123-140.

Innes, J., and Booher, D. (1999). "Consensus Building and Complex Adaptive Systems: A Framework for Evaluating Collaborative Planning" Journal of the American Planning Association, 65, 412-423. 
Jarillo, J.C. (1988). "On Strategic Networks" Strategic Management Journal, 9, 34-41.

Jorde, T.M., and Teece, D.J. (1989). "Innovation, Cooperation, and Antitrust:

Balancing Competition and Cooperation" High Technology Law Journal, 4(1).

Keast, R., and Brown, K. (2002). "The Government Service Delivery Network: A Case Study of the Push and Pull of Central Government Coordination" Public Management Review, 4 (4).

Keast, R., Brown, K., Mandell, M.P., and Woolcock, G. (2004). "Network Structures: Working Differently and Changing Expectations" Public Administration Review, 64(3), 363-371

Keast, R., Mandell, M.P., and Brown, K. (2005). "Governance Arrangements and Network Management: The Impact on Hybrid Networks" paper presented to the Ninth International Research Symposium on Public Management, Milan 6-8 April.

Kickert, W.J.M., Klijn, E-H., and Koppenjan, J.F.M. (1997). "Managing Networks in the Public Sector: Findings and Reflections". In W.J.M. Kickert, E-H Klijn, and J.F.M Koppenjan (eds.) Managing Complex Networks: Strategies for the Public Sector, Sage Publications, London, 166-188.

Leydesdorff, L. (2000). "The Triple Helix: An Evolutionary Model of Innovation" Research Policy, 29(2), 243-255. 
Limerick, D., Cunnington, B., and Crowther, F. (1998). Managing the New Organisation: Collaboration and Sustainability in the Postcorporate World, Business \& Professional Publishing, Warriewood, NSW.

Ling, Y.Y. (2003). "Managing the Implementation of Construction Innovations" Construction Management and Economics, 21, 635-649.

Lowndes, V., and Skelcher, C. (1998). "The Dynamics of Multi-Organisational Partnerships: An Analysis of Changing Modes of Governance" Public Administration, 76(2), 313-333.

Mackintosh, M. (1992). "Partnership: Issues of Policy and Negotiation" Local Economy, 7(3).

Mandell, M.P. (1988). "Organizational Networking: Collective Organizational Strategies" in J.Rabin, G.Miller. W. Bartley \& H. Ildreth (eds) Handbook of Strategic Management, Marcel Den Ker Inc. New York.

Mandell, M. P. (1994). "Managing Interdependencies Through program Structures: A Revised Perspective" American Review of Public Administration, 24(1), 99-121.

Mandell, M.P. (1990). Network Management: Strategic Behavior in the Public Sector. In R.W. Gage and M. P. Mandell (eds). Strategies for Managing Intergovernmental Policies and Networks (20-53) New York: Praeger, 20-53.

Mandell, M.P. (2000). "From Networks to Network Structures: Collaborative Strategies". In J. Rabin, G. Miller and W. Hildreth (eds.) Handbook of Strategic Management, $2^{\text {nd }}$ Edition, Marcel Dekker, New York, 371-385.

Mandell, M.P., and Steelman, T. (2003). "Understanding What can be Achieved Through Interorganizational Innovations: The Importance of Typologies, Context and Management Strategies" Public Administration Review, 5(2), 197- 
Marshall, C., and Rossman, G.B. (1989). Designing Qualitative Research, Sage, Thousand Oaks.

Menard, C. (2002). "The Economics of Hybrid Organisations." Presidential Address ISNIE 2002, MIT September 29, < www.isnie.org>.

Miozzo, M., and Dewick, P. (2002). "Building Competitive Advantage: Innovation and Corporate Governance in European Construction" Research Policy, 31(6), 9891008

Nam, C.H. and Tatum, C.B. (1997). "Leaders and Champions for Construction Innovation" Construction Management and Economics 15: 259-70.

Patton, M.Q. (1990). Qualitative Evaluation: Research Methods, $2^{\text {nd }}$ Edition, Sage Publications, California.

Powell, W. W., Koput, K. W., and Smith-Doer, L. (1996). "Interorganizational collaboration and the locus of innovation: Networks of learning in biotechnology" Administrative Science Quarterly, 41(1), 116-145.

Rhodes, R.A.W. (1997). "From Marketisation to Diplomacy: It's the Mix that Matters" Public Policy and Administration, 12, 31-50.

Schaeffer, P., and Loveridge, S. (2002). "Towards an Understanding of Types of Public Private Cooperation" Public Performance and Management Review, 26 (2), 169-189.

Seadon, G., and Manseau, A. (2001). "Public Policy and Construction Innovation" Building Research and Information, 29(3), 182-196. 
Slaughter, E.S. (2000). "Implementation of Construction Innovations" Building Research \& Information 28 91): 2-17.

Swan, J., Scarbrough, H., Robertson, M. (2003). "The construction of 'communities of practice' in the management of innovation" Management Learning, 33(4).

Tatum, C.B. (1984). "What Prompts Construction Innovation?" Journal of Construction Engineering and Management, 110(3), 311-323.

Tatum, C.B. (1991). "Incentives Technological Innovation in Construction" in L.M. Chang (ed) Preparing for Construction in the $21^{\text {st }}$ Century - Proceedings of the Construction Conference, New York, ASCE, 447-452.

Thorell, H.B. (1986). "Networks: Between Markets and Hierarchies" Strategic Management Journal, 7, 37-51.

Walker, D., and Hampson, K. (2003). Developing Cross-Team Relationships" in D. Walker and K. Hampson (eds) "Procurement Strategies: A Relationship Based Approach", Blackwell Science Ltd, Oxford, 169-203.

Winch, G. (1998). "Zephyrs of Creative Destruction: Understanding the management of Innovation in Construction" Building Research and Information, 26, 268-279.

Yin, R. (2003). Case Study Research: Design and Methods, $3^{\text {rd }}$ Edition, Sage Publications, Thousand Oaks, CA. 